\title{
Relationship between seropositivity of Encephalitozoon cuniculi and renal biochemical markers in clinically healthy rabbits
}

\author{
Özcan ÖZKAN ${ }^{1}$, Banuçiçek YÜCESAN ${ }^{2}$, Selçuk PEKKAYA ${ }^{3}$, Mehmet Eray ALÇIĞIR ${ }^{4}$, \\ İsmayil Safa GÜRCAN ${ }^{5}$
}

\begin{abstract}
${ }^{1}$ Çankırı Karatekin University, Faculty of Sience, Department of Biology, 18100, Çankırı, ${ }^{2}$ Public Health General Directorate, Parasitology Laboratory, Ankara, ${ }^{3}$ Etlik Veterinary Control Central Research Institute, Biochemistry Laboratory, Ankara, ${ }^{4}$ Kırıkkale University, Faculty of Veterinary Medicine, Department of Pathology, Turkey, ${ }^{5}$ Ankara University, Faculty of Veterinary Medicine, Department of Biostatistics, Ankara, Turkey.
\end{abstract}

\begin{abstract}
Summary: Encephalitozoon cuniculi can cause latent disease, especially in lagomorphs and many wild and domestic animals in various countries. This infection is important for veterinary and public health because it is caused by a potentially zoonotic and opportunistic pathogen. The aim of this study was to investigate the relationship between seropositivity of $E$. cuniculi and renal function markers, which may be useful in predicting the disease in clinically healthy rabbits. In this study, the seropositivity of E. cuniculi infection in clinically healthy rabbits was determined, and necropsy findings were evaluated along with the results of renal function tests. In a laboratory rabbit breeding facility, enzyme-linked immunosorbent assay (ELISA) tests showed that 48 (49.5\%) of 97 rabbits were seropositive against E. cuniculi. Blood urea nitrogen (BUN) and creatinine levels were significantly elevated in seropositive animals. Two seropositive rabbits were necropsied to confirm the infection. According to histopathological findings in the kidney, degenerative changes and E. cuniculi spores were identified in the tubule epithelia. Serum creatinine $(p<0.001)$ and BUN $(p<0.01)$ levels were found to have a statistically significant relationship with the serological status of rabbits. Serological and histopathological methods are not routinely used in rabbits to diagnose E. cuniculi infection. The kidneys were one of the most affected organs in encephalitozoonosis in rabbits. As revealed in this study, the testing blood urea nitrogen and creatinine levels would be useful for the evaluation of general health status and renal function of the seropositive rabbits, and clinical interpretation as well.
\end{abstract}

Keywords: Biochemical markers, Encephalitozoon cuniculi, rabbit, renal function.

\section{Sağlıklı tavşanlarda Encephalitozoon cuniculi seropozitifliği ile böbrek biyokimyasal belirteçleri arasındaki ilişki}

Özet: Encephalitozoon cuniculi, özellikle tavşangillerde ve çeşitli ülkelerdeki birçok yaban ve evcil hayvanlarda latent hastalığa neden olabilmektedir. Bu enfeksiyon potansiyel olarak zoonotik ve firsatçı bir patojenden kaynaklandığından veteriner ve halk sağlığı için önemlidir. Bu çalışmanın amacı, klinik olarak sağlıklı tavşanlarda E. cuniculi seropozitifliği ve böbrek fonksiyon belirteçleri arasındaki ilişkinin, hastalığın tanısında yararlı olabileceğini araştırmaktır. Bu çalışmada, sağlıklı tavşanlarda E. cuniculi enfeksiyonunun seropozitifliği enzim bağlantılı immünosorbent testi (ELISA) ile belirlenmiş ve böbrek fonksiyon test sonuçları ile otopsi bulguları birlikte değerlendirilmiş̧ir. Bir laboratuvar tavşan yetiştirme tesisinde, ELISA testi, 97 tavşanın 48'inin (\%49.5) E. cuniculi'ye karşı seropozitif olduğunu göstermiştir. Seropozitif hayvanlarda kan üre nitrojen (BUN) ve kreatinin düzeyleri anlamlı olarak yüksek bulunmuştur. Serum kreatinin $(p<0.001)$ ve BUN $(p<0.01)$ düzeylerinin tavşanların serolojik durumu ile istatistik olarak anlamlı bir ilişkisi olduğu anlaşılmıştır. Enfeksiyonun doğrulanması için iki seropozitif tavşan otopsi edildi. Böbrekteki histopatolojik bulgulara göre tübül epitelinde dejeneratif değişiklikler ve E. cuniculi sporları tespit edilmiştir. Encephalitozoon cuniculi enfeksiyonunu teşhis etmek için tavşanlarda serolojik ve histopatolojik yöntemler rutin olarak kullanılmamaktadır. Böbrekler tavşanlarda ensefalitozoonosisde en çok etkilenen organlardan biridir. Çalışmanın da gösterdiği üzere, kan üre nitrojen ve kreatinin düzeylerinin belirlenmesi, seropozitif tavşanların böbrek fonksiyonlarının değerlendirilmes, klinik ve genel sağlık durumunu yorumlanması adına yararlı olabileceği anlaşılmaktadır.

Anahtar sözcükler: Biyokimyasal belirteçler, böbrek fonksiyonu, Encephalitozoon cuniculi, tavşan.

\section{Introduction}

Encephalitozoon cuniculi is a Gram-positive, obligate intracellular parasite distributed worldwide. This parasite can cause a potential latent infection in many wild and domestic animal species, including humans, and is best documented in the lagomorphs $(12,15,16,20)$. Encephalitozoonosis is one of the most common health problems in rabbits, and it is found at industrial and family farms and in pet, zoo and laboratory rabbits in many countries $(16,21,37)$. The determination of antibody 
serostatus is useful to confirm exposure to the parasite, but antibody serostatus is also reported not to be correlated with clinical signs of a true infection $(6,7,33)$, which ranges from a total lack of symptoms to sudden death in infected rabbits. Serologic assays such as enzyme-linked immunosorbent assay (ELISA) is considered to be the most useful tools for antemortem diagnosis of the infection in different populations $(6,8)$.

The rabbits' main organs primarily affected by the parasite are kidneys and brain. The antibodies develop three to four weeks after infection, parallel to the increased antibody titers over time, normally the first alterations occur in the kidney and later in the brain. The pathogen primarily localized in renal cortical tubular epithelium and sometimes in the glomerular epithelium. Consequently, histopathological changes occur and it may result in kidney failure. Later, renal disease leads to clinical polydipsia and polyuria $(10,16,17,33)$. In addition, postmortem findings such as histopathological signs and anatomic localization of the lesions are not proportionally correlated with antemortem symptoms (19, 33). Postmortem diagnosis of E. cuniculi is required for definitive diagnosis. Using this method, the spores can be identified in many chronically infected tissues $(1,33,36)$. Postmortem morphological lesions in the kidneys are characteristic pitted appearance of the shrunken fibrotic kidneys. The lesion often considered to be diagnostic for confirmation of the infection in rabbits. On the other side, renal damage in living animals, biochemical parameters mainly creatinine and blood urea nitrogen are used as important kidney function markers in the accurate diagnosis of the renal impairment. In rabbit breeding, changes in biochemical parameters can also be used as indicators of welfare status and provide important information for clinicians for monitoring many diseases $(9,25,29)$.

The main objective of this study is to determine the relationship between $E$. cuniculi seropositivity and biochemical renal function markers that may be useful in predicting the disease in clinically healthy rabbits. For this purpose, the serology of E. cuniculi infection and the results of renal function tests were evaluated in the context of autopsy findings in a laboratory rabbit breeding facility.

\section{Materials and Methods}

All animal practices have been assessed and approved by the National Animal Experiment Central Ethics Board in accordance with the national ethical regulation (2018/111334-2b).

Animals and blood samples: In this study, New Zealand white rabbits were breed as in vivo test material in a laboratory rabbit breeding facility. The animals were housed individually in Noryl cages in a controlled room under a temperature of 18 to $20^{\circ} \mathrm{C}$, relative humidity of $50 \pm 5 \%$ and a 12:12-hour light:dark cycle. The rabbits were fed a standard commercial pellet diet and provided with water ad libitum. The rabbits $(62 \hat{\jmath}, 35$ \& /3-41 months of age) were monitored for the health status. Each rabbit was checked daily for water and feed intake, and their urine and feces output was also tracked. The animals were examined monthly for weight gain. Blood samples were taken for serological and biochemical analysis under aseptic conditions from the marginal ear veins of each animal immobilized in a restraint box. Then the sera were separated and stored at $-20^{\circ} \mathrm{C}$ until the serological and biochemical analyses.

Serology: To determine the E. cuniculi specific antibody responses in the rabbits, an ELISA kit (Express Biotech International-USA) containing positive and negative controls (rabbit serum) was used according to the manufacturer's instructions. The difference between sample optical density (OD) and negative-control OD $(\Delta)$ was greater than or equal to 0.300 , the sample was evaluated as positive.

Biochemical analyses: In the serum samples, activity aspartate amino transferase (AST); alanine aminotransferase (ALT); gamma-glutamyl transferase (GGT); lactate dehydrogenase (LDH); alkaline phosphatase (ALP); concentrations of glucose, triglycerides, total cholesterol, albumin, total protein, creatinine and blood urea nitrogen (BUN); uric acid; creatin kinase $(\mathrm{CK})$; total bilirubin (TB); calcium $(\mathrm{Ca})$; phosphorus $(\mathrm{P})$ and magnesium $(\mathrm{Mg})$ were determined using a fully automated BT 3000 plus biochemistry analyzer (Biotecnica Instruments S.p.A., Italy) according to the manufacturers' instructions. Commercial diagnostic kits (Quimica Clinica Aplicada) were used for the determination of biochemical parameters. Analyzer compositions were completely adjusted to our needs for clinical chemistry. The biochemical analyzer was calibrated for the reference point, which facilitates accurate results for each biochemical marker. Reference standard controls were also run before each determination, and the values obtained for the different biochemical parameters were always within the expected ranges.

Histopathology: First, necropsy was performed to confirm the infection and to show how the infection had damaged the tissues affected. For this reason, two seropositive rabbits were selected randomly and examined postmortem after species specific-euthanasia protocol (xylazine $60 \mathrm{mg} / \mathrm{kg}$ and ketamine hydrochloride 100 $\mathrm{mg} / \mathrm{kg}$ via intramuscular injection), and all organs and tissues were examined. The pathological changes were recorded according to general macroscopic criteria. In particular, the changes in kidneys, brain, lung and liver were examined thoroughly. Samples from the tissues were collected for histopathological examination during the necropsy, and fixed in buffered $10 \%$ formalin for 24 hours. After the fixation, tissues were embedded in paraffin wax and processed according to routine methods. 
Sections of five microns in thickness were cut from paraffin blocks and stained with hematoxylin and eosin (H\&E). The findings, mainly in kidney and brain, were evaluated under a digital light microscope (Euromex).

Statistical analyses: The Kolmogorov-Smirnov and Shapiro Wilk normality tests were performed, with the number of subjects in infected and non-infected groups, respectively, to be more or less than fifty. After the normality tests, the logarithmic transformation was first applied to the variables with no normal distribution, then the variables were tested again in the normality test. The analysis determined that all the variables in the dataset showed the normal distribution feature. The difference between the mean values of the variables examined in infected and non-infected animals was analyzed via an independent sample t-test. The effects of gender and age on infected animals were analyzed via two-way analysis of variance, and the difference between the mean values of the variables according to gender were compared using a Bonferroni correction. Mean values of antibody titer were compared via an independent sample t-test. The descriptive statistics for the variables are given in terms of mean and standard deviation. In all statistical analyses, $p<0.05$ was taken as significant. Statistical analyses were performed using the SPSS V.22 statistical package program.

\section{Results}

Animals: The appetite of the animals was normal, and lethargy, weight loss, polydipsia and polyuria were not observed in the animals throughout the study. No clinical signs and no mortalities due to infection were seen. All the animals (n: 97) were evaluated as clinically healthy.

Serology: The examination of 97 rabbits using ELISA showed that $48(49.5 \%)$ were seropositive against the parasite. The gender distribution was $73 \%$ males and $27 \%$ females in seronegative animals and $54 \%$ males and $46 \%$ females in the seropositive group. In the seropositives, sex and age groups alone and the combined effects of these two factors were not statistically significant $(p>0.05)$.

Biochemistry: The biochemical parameters detected in the rabbits are given in Table 1. In seropositive rabbits, the levels of protein, ALP, BUN, creatinine, cholesterol, $\mathrm{P}$ and glucose were significantly higher than in seronegative animals. No significant differences were observed in terms of other biochemical markers between E. cuniculi seronegative and seropositive serum samples. Levels of albumin $(p<0.001)$ and urea $(p<0.01)$ in seropositive females were lower than in seropositive males. Furthermore, creatinine $(p<0.001)$ and urea $(p<0.001)$ levels of seropositive males were higher than those of seronegative males. On the other hand, $\mathrm{P}(p<0.001)$, cholesterol $(p<0.001)$ and glucose $(p<0.05)$ levels of seropositive males were lower than the seronegative males. In seropositive female rabbits, levels of creatinine $(p<0.001)$ and protein $(p<0.001)$ were higher than in seronegative females, but cholesterol $(p<0.05)$ and ALP $(p<0.001)$ levels of seronegative females were found to be higher than those of seropositive females. According to the two-way ANOVA results, gender-based differences between mean values in albumin, protein and urea variables were significant $(p<0.05)$ in seropositive rabbits.

Table 1. Changes in biochemical parameters of rabbits with Encephalitozoon cuniculi infection.

Tablo 1. Encephalitozoon cuniculi enfeksiyonu olan tavşanların biyokimyasal parametrelerinde değişiklikler.

\begin{tabular}{|c|c|c|c|c|c|c|c|c|c|}
\hline \multirow{3}{*}{ PARAMETERS } & \multicolumn{8}{|c|}{ CLINICALLY HEALTH ANIMALS } & \multirow{3}{*}{$\boldsymbol{P}$} \\
\hline & \multicolumn{4}{|c|}{ INFECTED } & \multicolumn{4}{|c|}{ NON-INFECTED } & \\
\hline & $\mathbf{N}$ & MEAN & S.E.M & $\% 95$ C.I & $\mathbf{N}$ & MEAN & S.E.M & $\% 95$ C.I & \\
\hline Albumin $(\mathrm{g} / \mathrm{L})$ & 48 & 46.87 & 0.57 & $45.20-48.15$ & 49 & 47.76 & 0.91 & $45.59-48.88$ & $p>0.05$ \\
\hline $\mathrm{AST}(\mathrm{U} / \mathrm{L})$ & 48 & 33.90 & 3.51 & $27.89-39.84$ & 48 & 33.98 & 2.29 & $27.11-40.51$ & $p>0.05$ \\
\hline Protein $(\mathrm{g} / \mathrm{L})$ & 48 & 72.83 & 0.99 & 70.95-74.37 & 47 & 68.00 & 0.76 & $65.40-69.26$ & $p<0.001$ \\
\hline ALP (U/L) & 48 & 48.98 & 5.81 & $29.72-98.18$ & 47 & 156.72 & 13.22 & $151.0-194.3$ & $p<0.001$ \\
\hline ALT (U/L) & 48 & 27.29 & 4.16 & $20.30-33.39$ & 47 & 28.17 & 2.18 & $23.49-38.15$ & $p>0.05$ \\
\hline GGT (U/L) & 48 & 10.09 & 0.83 & $8.80-11.44$ & 47 & 9.75 & 0.40 & $8.25-11.22$ & $p>0.05$ \\
\hline BUN (mg/dL) & 48 & 43.44 & 1.66 & $39.80-46.30$ & 47 & 36.62 & 1.73 & $33.16-40.50$ & $p<0.01$ \\
\hline Creatinine $(\mathrm{mg} / \mathrm{dL})$ & 48 & 1.16 & 0.04 & $1.06-1.26$ & 47 & 0.82 & 0.05 & $0.69-0.91$ & $p<0.001$ \\
\hline $\mathrm{Ca}(\mathrm{mg} / \mathrm{dL})$ & 48 & 13.16 & 0.17 & $12.89-13.44$ & 47 & 13.29 & 0.07 & $12.98-13.60$ & $p>0.05$ \\
\hline $\mathrm{CK}(\mathrm{U} / \mathrm{L})$ & 48 & 479.29 & 45.61 & $382.4-527.4$ & 47 & 565.11 & 51.20 & $410.7-624.5$ & $p>0.05$ \\
\hline LDH (U/L) & 48 & 357.19 & 27.18 & $310.1-404.9$ & 47 & 368.70 & 21.64 & $282.0-388.8$ & $p>0.05$ \\
\hline $\mathrm{TB}(\mathrm{mg} / \mathrm{dL})$ & 48 & 0.27 & 0.032 & $0.22-0.33$ & 47 & 0.26 & 0.023 & $0.18-0.31$ & $p>0.05$ \\
\hline $\mathrm{Mg}(\mathrm{mg} / \mathrm{dL})$ & 48 & 2.75 & 0.11 & $2.50-3.02$ & 47 & 2.42 & 0.14 & $2.25-2.84$ & $p>0.05$ \\
\hline $\mathrm{P}(\mathrm{mg} / \mathrm{dL})$ & 47 & 4.06 & 0.18 & $3.73-4.40$ & 47 & 5.23 & 0.15 & $4.93-5.68$ & $p<0.001$ \\
\hline Cholesterol $(\mathrm{mmol} / \mathrm{L})$ & 46 & 38.65 & 3.22 & $33.70-45.14$ & 47 & 53.21 & 3.56 & $54.80-67.40$ & $p<0.01$ \\
\hline Uric Acid $(\mathrm{mg} / \mathrm{dL})$ & 45 & 0.47 & 0.05 & $0.37-0.58$ & 47 & 0.50 & 0.05 & $0.37-0.60$ & $p>0.05$ \\
\hline Triglyceride (mg/dL) & 45 & 92.98 & 9.41 & 77.66-110.4 & 47 & 102.26 & 6.62 & $86.64-122.2$ & $p>0.05$ \\
\hline Glucose $(\mathrm{mg} / \mathrm{dL})$ & 45 & 116.16 & 3.82 & $106.6-126.4$ & 47 & 130.32 & 5.75 & $122.5-127.9$ & $p<0.05$ \\
\hline
\end{tabular}

C.I: Confidence interval.

C.I: Güven aralığı. 

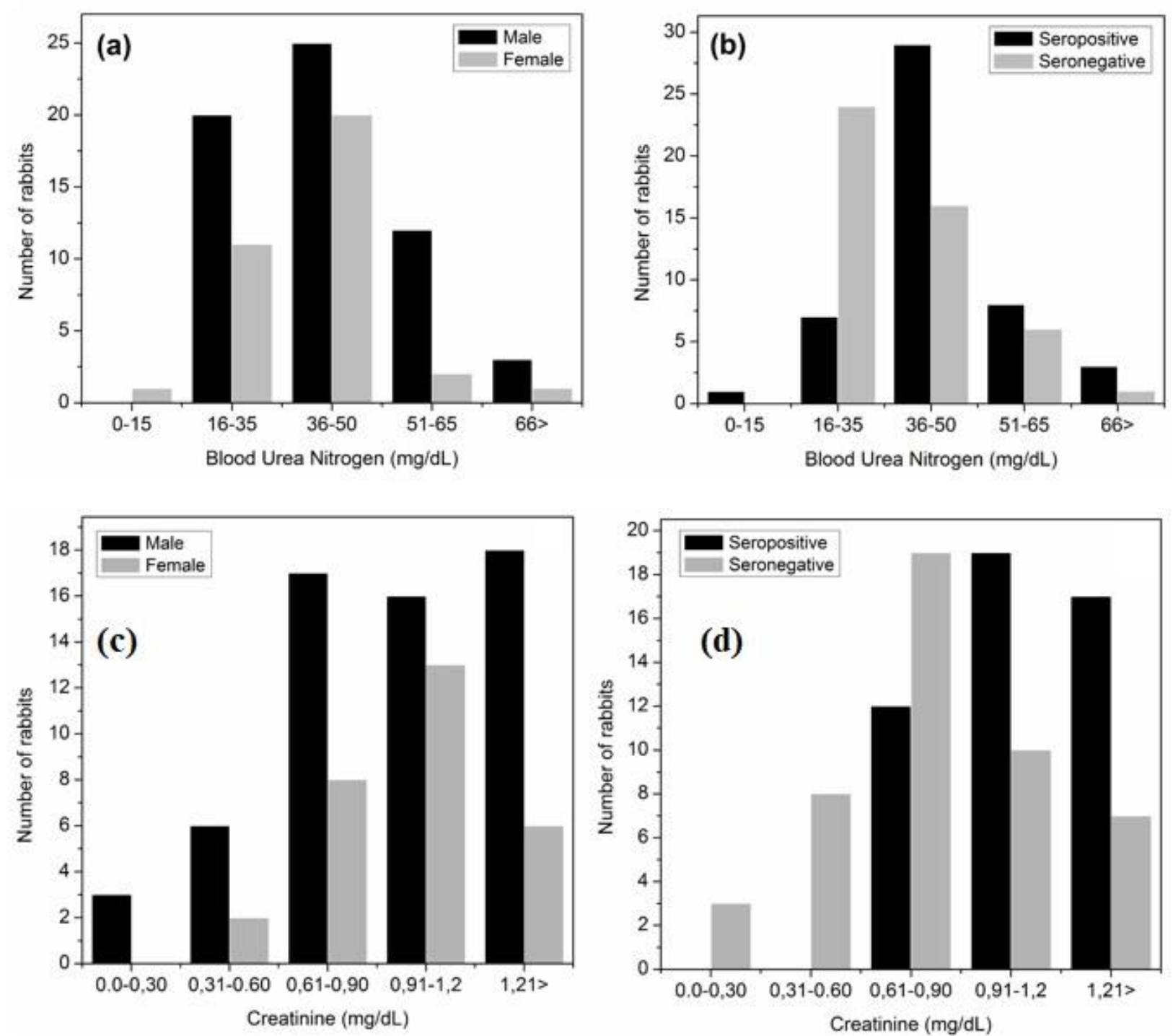

Figure 1. The blood urea nitrogen ( $a$ and $b$ ) and the creatinine ( $c$ and d) level of serum according to serostatus ( $b$ and d) of animals and gender ( $\mathrm{a}$ and $\mathrm{c}$ ) of rabbits.

Şekil 1. Hayvanların serolojik durumuna (b ve d) ve cinsiyete (a ve c) göre kan üre nitrojen (a ve b) ve serum kreatinin düzeyi (c ve d).

Serum, BUN and creatinine levels were significantly elevated in seropositive animals (Fig 1). However, the serum urea levels in these animals exhibited nonsignificant changes when compared to seronegative rabbits. Although the seropositive rabbits had azotemia and increased creatinine concentration, no clinical symptoms indicating the renal failure were inspected. In terms of these criteria, possible differences between genders have been evaluated, but no significant variation was detected.

Histopathology: Two seropositive rabbits were necropsied to confirm the infection, and specimens from their kidneys, brain, lung and liver were stained with $H \& E$ and examined under a light microscope at high magnifications for histopathological analysis. At necropsy, kidney tissues were observed to be normal in appearance, and there was no macroscopic damage (Fig 2A). The both cortical and medullar tubules were degenerated in kidneys of both animals according to histopathological findings. The degenerative changes were related to acute cell swellings and vacuolar degeneration. Most of the tubule epithelia had lost their typical pink cytoplasm. Their nuclei had lost their chromatin in many corticomedullar areas. E. cuniculi spores were identified in degenerated tubule epithelia. In the interstitial tissue of some corticomedullary junctions of the kidneys, mononuclear cell infiltrations composed of lymphocytes and macrophages were inspected multifocally. In the renal medulla, only a milder inflammatory response was seen, and such changes were observed only in a few interstitial areas (Fig 2B and C). In the brain, the meninges of both the cerebrum and 
cerebellum were hyperemic. The brain tissues were edematouse in appearance (Fig 2D). Histopathology of all brain tissue revealed that there were karyopyknosis in Purkinje cells and some demyelination areas in the substantia alba of the cerebellum. E. cuniculi spores were seen freely in some demyelinated areas, as well as degenerated neurons (Fig 2E and F). Additionally, there were some lesions in the liver. In the livers of both animals, mottled appearance and discolorisation were observed, with hyperemic and possibly degenerative areas (Fig 2G). Histopathology confirmed that there were hyperemia in the central veins and sinusoids and acute cell swelling in the hepatocytes, as well as Kupffer cell activations (Fig 2H). Another affected organ was the lungs. The lungs were hyperemic (Fig 2I); however, there were no mononuclear cell infiltrations and/or cell degenerations like those found in the kidney and the liver, except hyperemic capillaries.

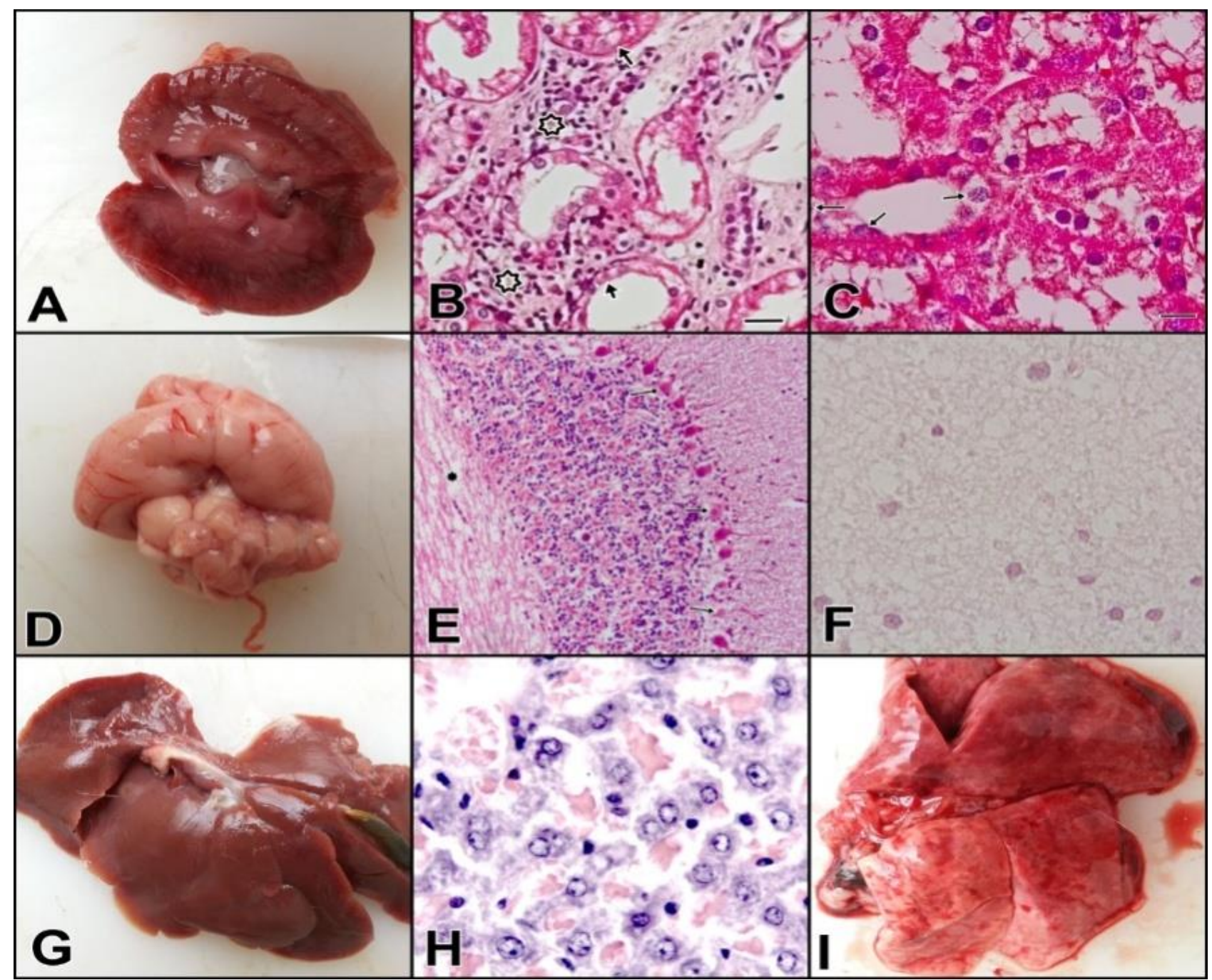

Figure 2. Macroscopical and histopathological findings in organs. A: Pale appearance in some cortex areas and hyperemia in the kidney. B: Mononuclear cell infiltration at interstitium (arrows) and degeneration in tubul epitheliums (arrows), x100, H\&E. C: Vacuolar degeneration in tubul epitheliums (arrows), kidney, x400, H\&E. D: Hyperemia in the cerebrum and cerebellum. E: Karyopyknosis in Purkinje cells (arrows) and demyelination areas (asterix) in cerebellum, x40, H\&E. F: Encephalitozoon cuniculi parasites in demyelinated areas of substantia alba in cerebellum, x250, H\&E. G: Vascular congestion and mottled discoloration due to pale areas in liver. H: Increase in Kupffer cell activations (arrows) and parenchymatous degeneration in hepatocytes (arrowheads), x400, HXE. I: Vascular congestion in lung.

Şekil 2. Organlarda makroskopik ve histopatolojik bulgular. A: Bazı korteks bölgelerinde solgun görünüm ve böbrekte hiperemi. B: İnterstisyumda mononükleer hücre infiltrasyonu (oklar) ve tubul epitelyumlarında dejenerasyon (oklar), x100, H\&E. C: Tubul epitelyumlarında vakuolar dejenerasyon (oklar), böbrek, x400, H\&E D: Serebrum ve serebellumda hiperemi. E: Serebellumda Purkinje hücrelerinde (oklar) ve demiyelinasyon bölgelerinde (asteriks) karyopyknosis x40, H\&E F: Serebellumda substantia albanın demiyelinize bölgelerinde Ensephalitozoon cuniculi parazitleri x250, G: Karaciğerdeki damar tıkanıklığı nedeniyle soluk alanlar ve benekli renk değişimi. H: Kupffer hücre aktivasyonlarında artış (oklar) ve hepatositlerde (ok başı) parankim dejenerasyonu. x400, H\&E I: Akciğerde konjesyon. 


\section{Discussion and Conclusion}

Rabbits are widely used as a model for in vivo studies, including in biomedical studies, surgery, atherosclerosis research, antibody production $(5,39,43)$. E. cuniculi was first recognized in laboratory rabbits by Wright and Craighead. It has been reported since 1922 in various studies in veterinary and human medicine employing different serologic diagnostic tools in numerous sample sizes and hosts $(23,30,31,38,40)$. Most latent E. cuniculi infections do not cause clinical symptoms, so the ability to diagnose these infections is very limited. In addition, these infections can have a significant effect on the outcome of in vivo studies. Therefore, screening for this infection has been recommended by the Federation for Laboratory Animal Science Associations for the health monitoring programme of breeding and experimental colonies, particularly in small laboratory animals (22). In the present study, we investigated the role of renal function biochemical markers, which may be useful in predicting the infection in clinically healthy rabbits.

The infection is routinely diagnosed with antemortem clinical findings, but the clinical diagnosis is not easy in living rabbits because $E$. cuniculi infection has a subclinical course. Specific antibodies develop within 21 days post-infection $(11,33)$. In clinically healthy rabbits, the present study showed that the seropositivity rate for $E$. cuniculi infection was $49.5 \%$, which is similar to rates $(50-53 \%)$ of infection in previous studies $(6,14,20)$, although it is higher than the rates of infection reported in some $(4,13,17,26,28,30-32)$. In contrast, in the current study, the seropositivity rate of the disease was lower than those previously reported (71-93\%) in various countries $(3,10,21,37)$. Serostatus was also investigated by sex, and no difference was found between sexes in terms of seropositivity (Fig 1). There is strong variability between reports, which may be due to varying breeding practices, husbandry conditions and hygiene rules across facilities and immune status of animals. It is difficult to reduce the prevalence of the infection because the disease is spread by spores excreted in the urine of infected animals.

In infected rabbits, clinical symptoms of renal insufficiency such as weight loss, numbness and loss of appetite may be seen, and some rabbits may develop urinary incontinence and become polydipsic and polyuric (36). In our work, no clinical signs were seen throughout the study. Nevertheless, laboratory analysis can be helpful in identifying the cause and degree of renal damage in living animals, and for this reason, biochemical markers of kidney function such as creatinine, urea, uric acid and electrolytes play an important role in the accurate diagnosis of renal impairment $(17,25,33)$. In rabbits, from another angle, the results of biochemical tests can be difficult to interpret in the diagnosis of renal disease, but levels of serum urea nitrogen and creatinine are still assessed as indicators of impaired renal function in animals. Harcourt-Brown (10) also reported that elevated urea and creatinine concentrations in blood are usually associated with renal disease and antibody response to $E$. cuniculi. In the current study, no direct clinical evidence was determined for renal disease in apparently healthy animals, but BUN and creatinine concentrations were found to be higher in seropositive animals than in seronegative ones (Fig 1). High levels of urea and, especially, high creatinine levels could be associated with E. cuniculi infection in rabbits. Significantly increased serum creatinine levels in seropositive animals could be attributed to the renal lesions induced by $E$. cuniculi spores. In our study, serum creatinine $(p<0.001)$ and BUN $(p<0.01)$ levels were found to have a statistically significant relationship with the serological status of rabbits (Table 1). Our results are consistent with those of previous studies $(1,3,10,33)$. On the other hand, numerous studies have reported that blood biochemistry parameters can be used to measure differences between animals. There are some factors related to the animals (age, species, strain and sex), environmental conditions, bleeding, sampling procedures and analysis method (24, 27). In this respect, apart from these factors, the autopsy was performed to demonstrate and confirm that the damage to the rabbit kidney was pathogen-dependent after serological and biochemical analysis. Twenty-eight days after infection, pathological lesions appear in the kidneys, and at this time, spores can be found in the urine. In rabbits, the first and most significant alterations are in the kidneys. The infection causes severe inflammation, interstitial nephritis and finally chronic renal impairment, but the most common clinical findings are neurological signs $(1,2,18,25,33,41,42)$. In the early stages of encephalitozoonosis, the spores are found in renal tubules, epithelial cells or macrophages and within the collecting ducts as free, with minimal involvement of the glomeruli. In our study, after evaluating all tissues mainly kidney, brain, as well as tissues of other parenchymatous organs, such as the liver and the lungs tissue was selected for postmortem diagnosis because parasite spores were detected more frequently in kidney tissue than in any other tissue. According to previous data pertaining to histological studies, an area containing dark red and grey, depressed, irregular pits and subcapsular foci on the surface of the renal cortex is considered indicative of encephalitozoonosis during necropsy $(1,34-36)$. In our study, there were no conspicuous findings macroscopically. However, histopathologically, epithelia of the cortical and medullary tubules were degenerated due to acute cell swellings and vacuolar degeneration in the early stages of encephalitozoonosis. The organism can be found within epithelial cells, macrophages, 
inflammatory foci or free within collecting tubules. Tubule epithelia had lost their pink cytoplasm, and $E$. cuniculi spores were detected in degenerated tubule epithelia. Mononuclear cell infiltrations were seen in the interstitium of renal tissues. The spores caused a milder inflammatory response in the renal medulla. These changes were observed only in a few interstitial areas. Rodríguez-Tovar et al. (36) reported that the inflammatory reaction could have occurred in the cortical regions of the kidney. In our study, inflammatory foci were also observed in the interstitium of kidneys. On the other hand, the same authors again have documented that granulomatous foci in other organs might be seen, and these foci might mask the E. cuniculi spores. In our study, we did not encounter any granulomatous foci or $E$. cuniculi spores in the liver or the lungs. Other internal and parenchymatous organs did not already show either these inflammatory reactions or degeneration caused by the parasite. The lesions were located only in the liver and the lungs. Particularly, the hepatocytes degenerated as well as the Kupffer cell activations. This situation demonstrates that the parasite can select a particular organ, such as the kidneys and the central nervous system.

In conclusion, recent studies on healthy rabbits, in particular, have shown that more than $50 \%$ of the rabbits were positive for $E$. cuniculi antibodies, but the clinical interpretation of the results was difficult. Serological and histopathological methods are not routinely used in rabbits to diagnose the infection. In E. cuniculi infection in rabbits, there are several clinical evidences including kidney failure, reduced appetite, weight loss, excessive water consumption and increased urine output. Because the pathogen was primarily localized in the kidney was affected organ, testing blood urea and creatinine levels would be useful for the evaluation of general health status and renal function of the rabbits, and for clinical interpretation as well. For this reason, possible organ damage caused by the infection in rabbits was interpreted according to the blood analysis results. We believe that serological tests, increased BUN and creatinine levels, in particular, might be useful indicators for diagnoses of renal damage in E. cuniculi infected in laboratory animals.

\section{References}

1. Abu-Akkada SS, Oda SS (2016): Prevention and treatment of Encephalitozoon cuniculi infection in immunosuppressed rabbits with fenbendazole. Iran J Vet Res, 17, 98-105.

2. Al-Sadi HI, Al-Mahmood, SS (2013): Microsporidial infection in some domestic and laboratory animals in Iraq. Int J App Basic Med Res, 3(3), 78-91.

3. Archetti I, Tittarelli C, Cerioli M, et al. (2008): Serum chemistry and haematology values in commercial rabbits; preliminary data fromindustrial farms in Northern Italy. In: 9th World rabbit congress: June, 10-13, 2008 Verona: Proceedings Castanet-Tolosan: WRSA. pp. 1147-1151.

4. Boot R, Hansen AK, Hansen CK, et al. (2000): Comparison of assays for antibodies to Encephalitozoon cuniculi in rabbits. Lab Anim, 34, 281-289.

5. Calasans-Maia MD, Monteiro ML, Ascoli FO, et al. (2009): The rabbit as an animal model for experimental surgery. Acta Cir Bras, 24, 325-8.

6. Cray C, Rodriguez M, Fernandez Y (2013): Acute phase protein levels in rabbits with suspected Encephalitozoon cuniculi infection. J Exot Pet Med, 22, 280-286.

7. Csokai J, Joachim A, Gruber A, et al. (2009): Diagnostic markers for encephalitozoonosis in pet rabbits. Vet Parasitol, 163, 18-26.

8. Dipineto L, Rinaldi L, Santaniello A, et al. (2008): Serological survey for antibodies to Encephalitozoon cuniculi in pet rabbits in Italy. Zoonoses Public Health, 55, 173-175.

9. Fuentes GC, Newgren J (2008): Physiology and clinical pathology of laboratory New Zealand White rabbits housed individually and in groups. J Am Assoc Lab Anim Sci, 47, 35-38.

10. Harcourt-Brown FM (2007): Radiographic signs of renal disease in rabbits. Vet Rec, 160, 787-794.

11. Harcourt-Brown FM, Holloway HK (2003): Encephalitozoon cuniculi in pet rabbits. Vet Rec, 152, 427431.

12. Hofmannová L, Sak B, Jekl V, et al. (2014): Lethal Encephalitozoon cuniculi genotype III infection in Steppe lemmings (Lagurus lagurus). Vet Parasitol, 205, 357-360.

13. Igarashi M, Oohashi E, Dautu G, et al. (2008): High seroprevalence of Encephalitozoon cuniculi in pet rabbits in Japan. J Vet Med Sci, 70, 1301-1304.

14. Keeble EJ, Shaw DJ (2006): Seroprevalence of antibodies to Encephalitozoon cuniculi in domestic rabbits in the United Kingdom. Vet Rec, 158, 539-544.

15. Kourgelis C, Reilly C, Von Roedern M et al. (2017): Serological survey for antibodies to Encephalitozoon cuniculi in cats within the United States. Vet Parasitol (Amst), 9, 122-124.

16. Künzel F, Fisher PG (2018): Clinical signs, diagnosis, and treatment of Encephalitozoon cuniculi infection in rabbits. Vet Clin North Am Exot Anim Pract, 21, 69-82.

17. Künzel F, Gruber A, Tichy A, et al. (2008) Clinical symptoms and diagnosis of encephalitozoonosis in pet rabbits. Vet Parasitol, 151, 115-124.

18. Künzel F, Joachim A (2010): Encephalitozoonosis in rabbits. J Parasitol Res, 106, 299-309.

19. Latney LT, Bradley CW, Wyre NR (2014): Encephalitozoon cuniculi in pet rabbits: Diagnosis and optimal management. Vet Med: Research \& Reports, 5,169180.

20. Lavazza A, Chiari M, Claudia Nassuato C, et al. (2016): Serological investigation on Encephalitozoon cuniculi in pet rabbits in North-Central Italy. Journal of Exotic Pet Medicine 25, 52-59

21. Maestrini G, Ricci E, Cantile C, et al. (2017): Encephalitozoon cuniculi in rabbits: Serological screening and histopathological findings. Comp Immunol Microbiol Infect Dis, 50, 54-57. 
22. Mähler CM, Berard M, Feinstein R., et al. (2014): FELASA recommendations for the health monitoring of mouse, rat, hamster, guinea pig and rabbit colonies in breeding and experimental units. FELASA working group on revision of guidelines for health monitoring of rodents and rabbits. Lab Anim, 48, 178-192.

23. Mathis A, Weber R, Deplazes P (2005): Zoonotic potential of the microsporidia. Clin Microbiol Rev, 18, 423-445.

24. Matsuzawa T, Nomura M, Unno T (1993): Clinical pathology reference ranges of laboratory animals. $\mathrm{J}$ Vet Med Sci, 55, 351-62.

25. Melillo A (2007): Rabbit Clinical Pathology. Journal of Exotic Pet Medicine, 16, 135-145

26. Meng QF, Wang WL, Ni XT, et al. (2015): Seroprevalence of Encephalitozoon cuniculi and Toxoplasma gondii in domestic rabbits (Oryctolagus cuniculus) in China. Korean J Parasitol, 53, 759-763.

27. Mohri M, Sharifi K, Eidi S (2007): Hematology and serum biochemistry of Holstein dairy calves: age related changes and comparison with blood composition in adults. Res Vet Sci, 83, 30-39.

28. Okewole EA (2008): Seroprevalence of antibodies to Encephalitozoon cuniculi in domestic rabbits in Nigeria. Onderstepoort J Vet Res, 75, 33-38.

29. Ozkan C, Kaya A, Akgül Y (2012): Normal values of haematological and some biochemical parametersin serum and urine of New Zealand White rabbits. World Rabbit Sci, 20, 253-259.

30. Ozkan O, Ozkan AT, Karaer Z (2011): Encephalitozoonosis in New Zealand rabbits and potential transmission risk. Vet Parasitol, 179, 234-247.

31. Pan Y, Wang S, Liu X, et al. (2015): Seroprevalence of Encephalitozoon cuniculi in Humans and Rabbits in China.Iran J Parasitol, 10, 290-295.

32. Reusch B, Murray JK, Papasouliotis K, et al. (2009): Urinary protein: creatinine ratio in rabbits in relation to their serological status to Encephalitozoon cuniculi.Vet Rec, 64, 293-295.

33. Rich G (2010): Clinical update on testing modalities for Encephalitozoon cuniculi in clinically sick rabbits. Journal of Exotic Pet Medicine, 19, 226-230.

34. Rodríguez-Tovar LE, Castillo-Velázquez U, ArceMendoza AY, et al. (2016): Interferon $\gamma$ and interleukin 10 responses in immunocompetent andimmunosuppressed New Zealand White rabbits naturally infected with Encephalitozoon cuniculi. Dev Comp Immunol, 62, 82-88.
35. Rodríguez-Tovar LE, Nevárez-Garza AM, Armando TA, et al. (2016a): Encephalitozoon cuniculi: Grading the histological lesions in brain, kidney, and liver during. Primo infection outbreakin rabbits. Journal of Pathogens, Article ID 5768428, 9.

36. Rodríguez-Tovar LE, Villarreal-Marroquín A, Nevárez-Garza, AM, et al. (2017): Histochemical study of Encephalitozoon cuniculi spores in the kidneys of naturally infected New Zealand rabbits. J Vet Diagn Invest, 29, 269277.

37. Santaniello A, Dipineto L, Rinaldi L, et al. (2009): Serological survey of Encephalitozoon cuniculi in farm rabbits in Italy. Res Vet Sci, 87, 67-69. Doi: 10.1016/j.rvsc.2008.12.008.

38. Tsukad R, Tsuchiyama A, Sasaki M, et al. (2013): Encephalitozoon infections in Rodentia and Soricomorpha in Japan. Vet Parasitol, 198, 193-196. Doi: 10.1016/j.vetpar.2013.08.018.

39. Wang W, Xu R, Li J (2010): Production of native bispecific antibodies in rabbits. PLoS ONE. 5, e10879. Doi:10.1371/journal.pone.001087.

40. Wesonga HO, Munda M (1992): Rabbit encephalitozoonosis in Kenya. Lab Anim, 26, 219-221.

41. Valencakova A, Balent P, Petrovova E, et al. (2008): Encephalitozoonosis in household pet Nederland Dwarf rabbits (Oryctolagus cuniculus). Vet Parasitol, 153, 265269.

42. Valencakova A, Halanova M (2012): Immune response to Encephalitozoon infection review. Comp Immunol Microbiol Infect Dis, 35, 1-7.

43. Yanni AE (2004): The laboratory rabbit: an animal model of atherosclerosis research. Lab Anim, 38, 246-256.

Geliş tarihi: 12.06.2018 / Kabul tarihi: 01.03.2019
Address for Correspondence:
Prof. Dr. Özcan ÖZKAN
Çankırı Karatekin University,
Faculty of Science
Department of Biology,
18100, Çankırı, Turkey
E-mail: ozcanozkan@karatekin.edu.tr 